Biens Symboliques / Symbolic Goods

Revue de sciences sociales sur les arts, la culture et les idées

$4 \mid 2019$

Autonomies des arts et de la culture

\title{
The Restricted Autonomy of Journalism and
}

Cinema

L'autonomie sous contrainte du journalisme et du cinéma

La autonomía del periodismo y del cine

Julien Duval

Translator. Daniela Ginsburg

\section{CpenEdition}

\section{Journals}

Electronic version

URL: http://journals.openedition.org/bssg/337

DOI: $10.4000 /$ bssg.337

ISSN: 2490-9424

Publisher

Presses universitaires de Vincennes

Electronic reference

Julien Duval, "The Restricted Autonomy of Journalism and Cinema", Biens Symboliques / Symbolic Goods [Online], 4 | 2019, Online since 27 June 2019, connection on 04 March 2021. URL: http:// journals.openedition.org/bssg/337 ; DOI: https://doi.org/10.4000/bssg.337 


\title{
L'autonomie sous contrainte du The Restricted Autonomy of journalisme et du cinéma Journalism and Cinema
}

\author{
Julien Duval \\ traduction | translation \\ Daniela Ginsburg
}

\begin{abstract}
Élaborant le concept de " champ », Pierre Bourdieu a utilisé la notion d'autonomie que Kant, par exemple, dans le cas de l'Université, identifiait au principe selon lequel « seuls des savants peuvent juger des savants en tant que tels » (Kant 1997 [1798] : 13). Bourdieu, dans ses travaux empiriques, a privilégié des univers qui se rapprochaient de cette situation pure et qui, mieux que d'autres, lui permettaient de dégager les propriétés de champs conçus comme des " microcosmes " dotés de leurs propres lois. C'est en effet à l'art et à la littérature, ainsi qu'à la science et au monde universitaire, qu'il a consacré ses recherches les plus approfondies ; et c'est au sein de ces univers qu'il trouvait généralement ce qui lui apparaissait comme les meilleurs exemples de champs dotés d'un haut degré d'autonomie : les mathématiques, la poésie ou l'art d'avant-garde (par exemple, Bourdieu $2000: 60$ ).
\end{abstract}

In developing his concept of "field," Pierre Bourdieu used the notion of autonomy that Kant, in the case of the university, for example, defined as the principle that "only scholars can pass judgment on other scholars as such" (Kant 1992 [1798]: 23). In his empirical works, Bourdieu favoured universes that are similarly "pure" and which, more than others, allowed him to identify the properties of fields understood as "microcosms" ruled by their own laws. He dedicated his most in-depth research to art, literature, science, and the academic world; within these universes, he found what appeared to him to be the best examples of fields with a high degree of autonomy: mathematics, poetry, and avant-garde art (for example, Bourdieu 2000: 60). 


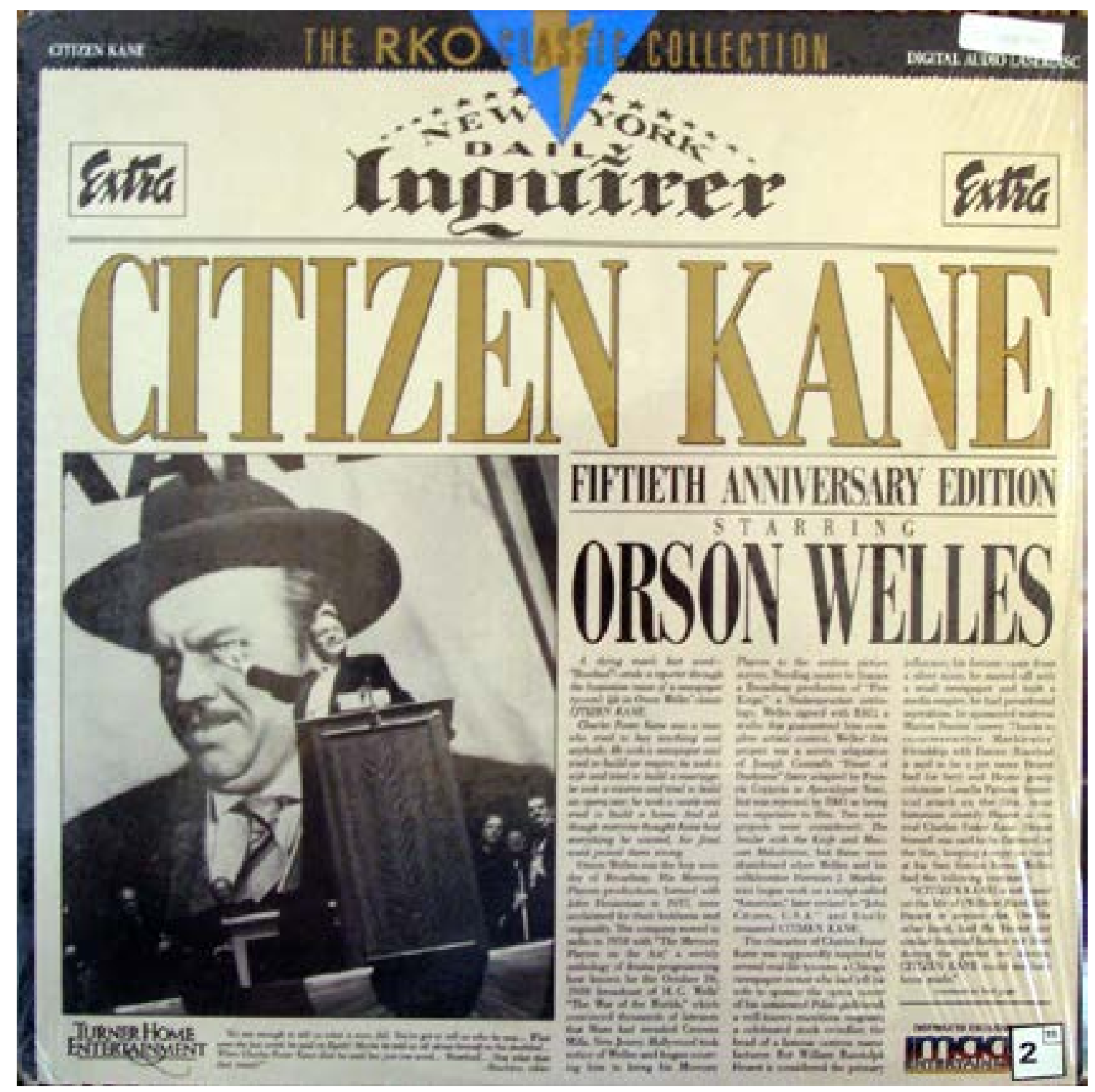


Le présent texte rassemble des remarques issues de travaux sur le journalisme économique et le cinéma en France ${ }^{1}$, deux espaces sociaux à l'évidence beaucoup moins facilement assimilables à de pures activités de spécialistes dont tout public profane et toute force externe auraient été écartés. La démarche - qui se limite au cas français - vise à engager une analyse comparative entre ces deux univers à l'aune du cas sociologiquement (mais peut-être aussi historiquement) paradigmatique que représente le champ littéraire. Dans quelle mesure des aspirations à l'autonomie sontelles possibles dans ces univers qui, comme le journalisme ou le cinéma, sont en quelque sorte structuralement hétéronomes ? Sous quelles formes peuvent-elles se réaliser ? L'examen simultané de ces deux univers, dont les évolutions au $x x^{e}$ siècle présentent un certain parallélisme, invite aussi à considérer que toutes les périodes ne sont pas également favorables à l'autonomisation des univers sociaux et que cette dernière, par conséquent, pourrait participer d'une dynamique sociale générale.

\section{Un modèle à double titre}

C'est au sujet de l'art et de la littérature que Pierre Bourdieu a le plus développé sa réflexion sur l'autonomie des champs (Bourdieu 1971, 1992b). Il évoque une autonomisation progressive des artistes et des intellectuels, à partir de la situation de quasi-monopole que l'Église, au Moyen Âge, exerçait sur la production culturelle. Le

1. Ce texte s'appuie sur deux recherches où l'on avait prêté une attention particulière à la question de la relation de ces univers avec l'économie. Nous nous permettons de renvoyer à des publications antérieures (Duval 2004 ; 2016) pour des développements sur des points qu'il n'était pas possible de traiter ici en détail. On peut rappeler que Pierre Bourdieu s'est intéressé au problème de l'autonomie du journalisme dans les années 1990 (Bourdieu 1996) et qu'il a formulé des remarques ponctuelles sur le cinéma (Bourdieu $1992 b$ : 336, 338 ; Bourdieu 2002 : 417-424)
This article contains observations from my research on economic journalism and cinema in France ${ }^{1}$-two social spaces that appear to be much less easily characterized as pure specialist activitiesthat is, activities from which any lay audience and any external force have been removed. Limiting myself to the French case, I carry out a comparative analysis of these two universes in light of the sociologically (and perhaps also historically paradigmatic) example of the literary field. To what extent are aspirations to autonomy possible in universes such as journalism and cinema, which are in a sense structurally heteronomous? In what forms might these aspirations be realized? Simultaneous examination of these two universes, which experienced somewhat parallel development during the twentieth century, also invites us to consider that not all periods are equally favourable to the autonomization of social universes, and that consequently, autonomization might be part of a larger general social dynamic.

\section{A Double Model}

Pierre Bourdieu developed his thoughts on the autonomy of fields by studying the subjects of art and literature in particular (Bourdieu 1971: 1996). He discusses the gradual autonomization of artists and intellectuals in the wake of the near-monopoly that the Church had over cultural productions in the Middle Ages. Patronage and aristocratic and royal protection contributed to a

1. This text is based on two earlier works that paid particular attention to the question of the relationship between these universes and the economy. For more detail on points that it is not possible to discuss in depth here, see (Duval 2004) and (Duval 2016). We may recall that Bourdieu became interested in the issue of the autonomy of journalism during the 1990s (Bourdieu 1998) and that he made a few remarks on cinema (Bourdieu 1996: 162, 164; Bourdieu 2002: 417-424) 
mécénat et les protections aristocratiques et royales ont contribué à une forme de sécularisation, avant que le «marché » ne permette aux artistes de rompre les liens de dépendance avec un « commanditaire ». Bourdieu insiste cependant sur l'ambivalence de ces forces, alternativement libératrices ou aliénantes, selon les époques ou les domaines culturels. Le même «marché » qui aide Rembrandt (Alpers 1991 [1988]) ou Beethoven (Bourdieu 2001a) à se libérer des servitudes du mécénat est par exemple perçu, au moment du développement de la « littérature industrielle », par les romantiques puis par les théoriciens de "l'Art pour l'art » comme une subordination, cette fois aux demandes du " grand public ». Le $\mathrm{XIX}^{\mathrm{e}}$ siècle marque une accélération brutale du mouvement d'autonomisation, que Bourdieu analyse dans Les Règles de l'art. "L'affirmation [...] du droit des artistes à légiférer absolument dans leur ordre, celui de la forme et du style " (Bourdieu 1971 : 51-54), conduit à la constitution, à côté du secteur de production élargi régi par les verdicts économiques, d'un sous-champ de production restreinte fortement autonome par rapport à ces derniers et où comme dans la poésie d'avant-garde, les écrivain·e·s tendent à n'avoir plus pour client.e.s que leurs concurrente.'s (Bourdieu 1992b). L'autonomisation est l'affirmation élitiste du primat de la forme et implique le double refus de glorifier les dominant.e.s comme d'instruire les dominé·e·s (Bourdieu 1992b : 118). Le mouvement se propage des genres littéraires les plus « purs » aux plus " commerciaux ", et à d'autres secteurs artistiques comme la peinture (Bourdieu 2013). Les Règles de l'art ont pour objet principal la " genèse et [la] structure du champ littéraire ", mais le livre propose un modèle de portée plus large : il y est énoncé, par exemple, que « les champs de production culturelle s'organisent, très généralement, en l'état actuel, selon un principe de différenciation qui n'est autre que la distance objective et subjective des entreprises de production culturelle à l'égard du marché et de

la demande exprimée ou tacite [...] » (Bourdieu 1992b : 202). form of secularization, before the 'market' allowed artists to break their bonds of dependence on a "sponsor." However, Bourdieu emphasizes the ambivalence of these forces, which were alternately liberating or alienating, depending on the period and the cultural domain. The same "market" that helped Rembrandt (Alpers 1988) or Beethoven (Bourdieu 2001) free themselves from the servitude of patronage was, for example, perceived by the Romantics at the moment of the development of "industrial literature," and then later by theoreticians of "art for art's sake," as simply another form of subordination-this time, to the demands of the "public." The nineteenth century marked an abrupt acceleration of the movement of autonomization, which Bourdieu analyses in The Rules of Art. "The affirmation of $[. .$.$] the right of artists to legislate within their$ own sphere-that of form and style" (Bourdieu 1993: 2) led to the creation, alongside the enlarged sector of production, governed by economic concerns, of a restricted sub-field of production, highly autonomous with regard to those concerns and where, as in avantgarde poetry, writers' only clients tended to be their competitors (Bourdieu 1996). Autonomization here is an elitist affirmation of the primacy of form, and it implies a double refusal: the refusal either to glorify the dominants or to educate the dominated (Bourdieu 1996: 79). The movement spread from the 'purest' literary genres to the most "commercial" ones, and to other sectors such as painting (Bourdieu 2017). The subject of Bourdieu's The Rules of Art is the "genesis and structure of the literary field," but the book proposes a model that can be applied more broadly. He writes, for example, that "the fields of cultural production are organized, very generally, in their current state [according to a] principle of differentiation": "the objective and subjective distance of enterprises of cultural production with respect to the market and to expressed or tacit demand" (Bourdieu 1996: 141). 
Bourdieu lui-même a cherché à étendre ses analyses au cas du journalisme (Bourdieu 1996). L'histoire de la presse a été longtemps parallèle à celle du livre. Sous l'Ancien Régime, elle était soumise à un régime de censure et d'autorisation préalable très comparable (Bellanger 1972). Au $\mathrm{XIX}^{\mathrm{e}}$ siècle, se développe une " presse industrielle " et apparaît bientôt une division entre un pôle régi par les gros tirages et des journaux "sérieux " (Bourdieu 1996). L'opposition entre les views et les news se perpétue de nos jours, avec la coexistence de médias " populaires ", parfois " sensationnalistes » et souvent très rentables, et d'une presse « de qualité » au lectorat plus étroit et surtout plus élitaire (Bourdieu 1979). Son refus des « facilités commerciales » l'expose à des difficultés économiques endémiques mais elle bénéficie d'un prestige spécial dans la profession.

La fin $\mathrm{du} x \mathrm{XX}^{\mathrm{e}}$ siècle et les premières décennies $\mathrm{du} x \mathrm{x}^{\mathrm{e}}$ siècle ont marqué l'apparition de pratiques et d'institutions durables qui participent de formes d'autonomie journalistiques. Ainsi, autour de 1900 , la pratique du reportage, dans laquelle le ou la journaliste produit (et non relaie) des informations, est importée des ÉtatsUnis. À la même époque, la première école de journalisme, à l'origine de l'actuelle École supérieure de journalisme (ESJ) de Paris, est créée. Elle recrute ses intervenant·e.s dans la presse " sérieuse " et entend contribuer à la formation de journalistes « intègres » qui s'abstiennent de déformer les faits pour complaire à des demandes du " grand public » ou de pouvoirs politiques ou économiques. L'hebdomadaire satirique Le Canard enchaîné né en 1916 dans le contexte de la censure de guerre affiche, lui, au travers de l'antiphrase que constitue son titre, le droit de ses rédacteur-rice-s à décider seul·e.s de ce qu'ils et elles publient. L'apparition de prix professionnels manifeste la revendication des journalistes à dire eux-mêmes ce que doit être un·e bon'ne
Bourdieu himself sought to extend his analysis to the case of journalism (Bourdieu 1998). This history of the press has long run parallel to that of books. In France, under the Ancien Régime, the two were subject to very similar censorship systems and requirements of prior authorization (Bellanger 1972). In the nineteenth century, the "industrial press" began to develop, and a division soon appeared between the high-circulation press and "serious" newspapers (Bourdieu 1998). The opposition between "views" and "news" still exists today, with the co-existence of the "popular" media-sometimes "sensationalist," and often very profitable - on the one hand, and the "quality" press on the other, with its narrower-and more elitist-readership (Bourdieu 1984). The latter's refusal of "commercial arrangements" exposes it to endemic economic difficulties, but it benefits from a special prestige within the profession.

The end of the nineteenth century and the first decades of the twentieth saw the appearance of enduring practices and institutions that participated in journalistic forms of autonomy. Thus, around 1900, the practice of reporting-where the journalist produces information rather than simply passing it on-was imported from the United States. At the same time, the first school of journalism was created, the origin of today's École supérieure de journalisme [ESJ] in Paris. It recruited professionals from the "serious" press and sought to train journalists with "integrity," who would refrain from distorting the facts to comply with the demands of the "general public" or political or economic powers. The antiphrastic title of the satirical weekly Le Canard enchaîné ${ }^{2}$, which was founded in 1916 in the context of war censorship, proclaimed the right of its editors to decide, on their own, what they would publish. The

2. The adjective "enchainé" (chained) refers to wartime censorship; the noun "canard" (literally, a duck), is a slang term for a newspaper. 
journaliste. Le prix de reportages Albert Londres, « reconnaissance professionnelle, de professionnels à l'égard de professionnels » (Gatien 2012 : 232), est décerné à partir de 1933. Il récompense la conformité de reporters aux valeurs du groupe, en même temps qu'il les met en concurrence et les invite, comme dans un champ artistique ou scientifique autonome, à se distinguer les un.e.s des autres par l'originalité. II constitue un capital spécifique qui a d'abord et surtout valeur dans le monde journalistique.

Apparu à la fin du XIX ${ }^{\mathrm{e}}$ siècle, le cinéma s'organise pour sa part, dès les années 1920, autour d'un pôle de grande diffusion tourné vers la réalisation de profits économiques et un pôle orienté vers la recherche formelle mais ne disposant que d'un public étroit et socialement sélectionné. Parmi de nombreux indices, une lettre que le cinéaste Carl Dreyer adresse en 1919 à un producteur qui songe à s'engager dans le financement de l'un de ses films montre que le vocabulaire et les valeurs de l'autonomie artistique se sont diffusés très tôt dans le domaine du cinéma : le réalisateur exprime son refus de tenir compte de quelque considération "commerciale" que ce soit, au nom des « exigences de l'art » qu'il est « seul à pouvoir [...] juger » (Dreyer 1968). L'opposition entre un « cinéma de producteur-rice » et un « cinéma de metteur.se en scène » a perduré et s'exprime dans les distinctions communes qui, pour rester floues, n'en renvoient pas moins à des différences objectives, entre films " commerciaux » et « d'auteur.e », «populaires » et " élitistes », " mainstream » et « indépendants », etc. II existe, chez certain·e.s cinéastes, une aspiration à contrôler la forme, en l'occurrence « la mise en scène ", sans anticiper sur les verdicts économiques et le jugement du grand public.

$\mathrm{Si}$, dans ses grands traits tout au moins, le modèle proposé par Pierre Bourdieu à partir du cas de la littérature s'étend aussi facilement au appearance of professional prizes attests to journalists' claim to determine for themselves what it means to be a good journalist. The Albert Londres Prize for reporting, "professional recognition of professionals by professionals," (Gatien 2012: 232) was first awarded in 1933. The prize rewards reporters' compliance with the values of the group, and at the same time, creates competition between them and invites them to distinguish themselves through their originality. It constitutes a specific capital that has value first and foremost in the world of journalism.

As for cinema, which began at the end of the nineteenth century, beginning in the 1920s it became organized around a mass-market pole, oriented towards economic profits, and another pole oriented towards explorations of form, with a narrow and socially selected audience. Among many other indications, a 1919 letter from the director Carl Dreyer to a producer who hoped to finance one of his films shows that the vocabulary and values of artistic autonomy spread to cinema very early on. The filmmaker expresses his refusal to take any "commercial" considerations whatsoever into account, in the name of the "exigencies of art," which he is "the only one able [...] to judge" (Dreyer 1968). The opposition between a "cinema of producers" and a "cinema of directors" has endured, and is expressed in common distinctions between "commercial" and "art" films, or between "elitist," "mainstream," and "independent" films. Although these distinctions remain blurry, they nevertheless correspond to objective differences. Some filmmakers aspire to control the form of their works, that is, the "mise-en-scène," without thinking about economic consequences or the opinions of the general public.

If the main traits of Pierre Bourdieu's model, based on the case of literature, can be rather easily extended to the cases of journalism 
journalisme et au cinéma, c'est que la littérature les a en un sens modelés. En effet, l'autonomisation des champs journalistique et cinématographique s'est en partie opérée par des transferts d'agent·e.s, de pratiques ou de critères d'évaluation en provenance du champ littéraire. Celui-ci a joué un rôle de premier plan dans la naissance du journalisme moderne (Ferenczi 1993). Les « qualités de plume » restent aujourd'hui prisées dans certains secteurs ou certaines institutions journalistiques. Les candidat.e.s au prix Albert Londres conservent ainsi une propension à se penser sur le modèle de l'écrivain·e (Gatien 2012). La figure héroïque du ou de la journaliste qui affronte des intérêts économiques et politiques pour faire éclater une « vérité » et qui naît en France avec Albert Londres dans les années 1920 n'est pas étrangère à celle de « l'intellectuel » que des écrivain·e·s, Émile Zola au premier chef, avaient inventée au moment de l'affaire Dreyfus. La littérature fut également l'un des moteurs de l'autonomisation du cinéma. Les représentant·e·s des avant-gardes littéraires ont été parmi les premier-ère-s à produire des discours savants sur le cinéma et se sont parfois investi·e.s directement dans les premières avant-gardes cinématographiques au lendemain de la Première Guerre mondiale (Duval 2016 : 131-142). Des écrivain·e·s plus académiques ont souvent siégé dans des instances dédiées à la consécration d'un « cinéma de qualité ». Le modèle de l'écrivain se repère aussi chez nombre des grands noms du « cinéma de mise en scène ", depuis David Griffith qui recherchait des équivalents cinématographiques de procédés romanesques jusqu'aux cinéastes de la Nouvelle Vague qui, après avoir échoué pour certains dans une carrière littéraire, aspiraient à « réaliser un premier film comme un romancier écrit son premier roman » (Mary 2006).

En fait, l'autonomisation relative de ces deux domaines paraît s'être inscrite dans un mouvement général qui a touché les espaces de production culturelle et qui a pris, à mesure que le contrôle de la vie culturelle par des pouvoirs politiques (et religieux) devenait plus and cinema, this is because in a sense, literature shaped journalism and cinema. Indeed, the autonomization of the journalistic and cinematic fields took place in part through the transfer of agents, practices, and criteria of evaluation from the literary field. This field had a major role in the birth of modern journalism (Ferenczi 1993). Today, "literary qualities" remain highly regarded within certain journalistic sectors and institutions. Thus, candidates for the Albert Londres Prize maintain a tendency to think of themselves as writers (Gatien 2012). The heroic figure of the journalist who takes on economic and political interests in order to expose the "truth" was born in France with Albert Londres in the 1920s, and is not unlike the figure of the "intellectual" invented by writers-first and foremost Émile Zola - at the time of the Dreyfus Affair. Literature was also one of the engines driving the autonomization of cinema. Representatives of the literary avant-garde were among the first to create scholarly discourses on cinema, and they sometimes participated directly in the first avant-garde films, during the postWorld War I period (Duval 2016: 131-142). Writers who were closer to academia often served in organizations dedicated to preserving "high-quality cinema." The writer model can also be found among many of the big names in "mise-en-scène cinema," from David Griffith-who sought the cinematic equivalents of novelistic procedures - to the French Nouvelle Vague filmmakers, some of whom, after failed literary careers, aspired to "make a first film in the same way a novelist writes her or his first novel" (Mary 2006).

In fact, the relative autonomization of these two domains appears to be part of a general movement that affected all the spaces of cultural production: as control over cultural life by political (and religious) powers decreased, cultural production began to 
secondaire, la forme privilégiée d'une mise à distance des verdicts économiques et des demandes du « grand public ». En France du moins, la littérature a joué un rôle particulier, « libérateur » parce que pionnier. Bourdieu le mettait en valeur dans le cas de la peinture ${ }^{2}$. Les praticien'ne-s de cet « art total » qu'était réputé être le cinéma ont cependant aussi puisé des modèles dans la peinture ou la musique, de même que les journalistes ont pu se référer aux sciences sociales et - on y reviendra - à la politique (Ferenczi 1993). Tardivement touchés, le journalisme et le cinéma ont bénéficié d'emblée de certaines conquêtes obtenues par les espaces qui les avaient précédés. Très tôt, par exemple, des films ont porté sur des sujets historiques ou d'actualité que les peintres n'avaient pu traiter qu'au terme de très longues luttes. Mais la situation « cadette " confère au processus d'autonomisation une spécificité : comme les peintres (Bourdieu 2013), les journalistes et les cinéastes ont dû se libérer de la tutelle des activités « aînées ». Les premier·ère·s, par exemple, ont développé des conceptions de l'excellence professionnelle irréductible aux qualités de plume. Les second.e.s ont pu poser le primat de la mise en scène spécifiquement cinématographique, irréductible à la fois à la mise en scène théâtrale et à l'activité littéraire d'écriture d'un scénario.

\section{Une série de différences}

II existe bien sûr des différences entre le journalisme et le cinéma. Sans prétendre proposer un modèle méthodique, on peut essayer d'évoquer ici certaines de ces différences et des facteurs

susceptibles de les éclairer.

2. Bourdieu souligne cependant que les échanges ne sont pas univoques et parle d'une « course de relais » entre les écrivain·e.s et les peintres (Bourdieu 1992b, 2013) favour distance from economic concerns and the demands of the "general public." At least in France, literature played a particularly "liberating"-since it was pioneering-role. Bourdieu highlighted the trend in the case of painting. ${ }^{3}$ Practitioners of the "total art" that cinema was said to be also took models from painting and music, just as journalists referred to the social sciences and to politics, as I will discuss below (Ferenczi 1993). Journalism and cinema joined the trend rather belatedly, and they benefited from certain victories achieved by the spaces that preceded them. Very early on, for example, films touched on historical or contemporary subjects that painters only succeeded in depicting after long struggles. But being "juniors" meant that there was a specificity to the autonomization of journalism and cinema: just like painters (Bourdieu 2017), journalists and filmmakers had to free themselves from the tutelage of their "elder" activities. Journalists, for example, developed conceptions of professional excellence that were irreducible to literary style. Filmmakers posited the primacy of a specifically cinematic miseen-scène, irreducible both to theatrical staging and to the literary activity of screenwriting

\section{A Series of Differences}

Of course, there are differences between journalism and film. Without claiming to propose a methodical model, I will try to discuss some of these differences and the factors that can shed light on them.

3. However, Bourdieu emphasizes that exchanges are not univocal, and he describes a "relay race" between writers and painters (Bourdieu 1996; 2017). 
Le cinéma constitue bien sûr un cas de figure sensiblement plus proche de la littérature que le journalisme. C'est qu'il s'inscrit plus fortement dans la sphère de la culture et de l'art qui passent, assez universellement sans doute, pour les traces les plus pérennes que laissent les civilisations (Sapir $1967: 160$ ) et qui, à l'inverse des produits de l'activité humaine voués à l'oubli ou à la destruction sitôt que consommés, font l'objet d'une transmission intergénérationnelle impliquant, dans nos sociétés, des institutions de conservation comme l'école ou les académies. Le cinéma a, surtout depuis la deuxième moitié $d u x^{e}$ siècle, fait l'objet d'une plus forte reconnaissance culturelle, même si sa place dans les programmes scolaires ou les institutions académiques reste sans commune mesure avec celle qui est accordée, de très longue date, à des œuvres et des producteur.rice.s littéraires. Ce statut de second rang ne facilite pas l'autonomisation du domaine : il peut donner aux velléités d'autonomie les apparences d'une prétention déplacée et il limite les profits que peut susciter, pour les pouvoirs temporels, le fait de renforcer son autonomie, ainsi que les coûts symboliques encourus à attaquer celle-ci.

Le cinéma ne diffère pas seulement de la littérature par sa moindre légitimité, mais par une série de facteurs qui, souvent, se redoublent les uns les autres. Son public est nettement plus large et, du même coup, plus hétérogène et socialement moins sélectionné. II s'expose à paraître moins " adulte " à des autorités sociales portées à réclamer ou à exercer, pour cette raison, une censure plus forte. Au début du $\mathrm{xx}^{\mathrm{e}}$ siècle par exemple, au moment même où la censure est levée au théâtre, un système d'autorisation préalable est établi pour le cinéma qui détourne des théâtres une partie du public populaire. Autre différence : les coûts de production et de diffusion tendent à être beaucoup plus élevés dans le cas du cinéma que de la littérature. Les producteur.rice.s culturel-le.s ne doivent pas seulement, comme dans d'autres domaines, assurer leur subsistance mais aussi
Cinema is clearly closer to literature than journalism is: it is more strongly anchored in the sphere of culture and art, which are considered-no doubt fairly universally - to be the most enduring traces that human civilisations can leave (Sapir 1967: 160); and, unlike those products of human activity that are doomed to be forgotten or destroyed as soon as they are consumed, they are handed down from generation to generation. In our societies, this means there must be institutions that preserve them, such as schools or academies. Especially since the second half of the twentieth century, cinema has received greater cultural recognition, even though its place in school curricula and academic institutions cannot be compared with the place that has long been granted to literary works and authors. This second-tier status does not facilitate the autonomization of the domain: it can make the dream of autonomy seem like misplaced pretentiousness and it limits the profits that reinforcing autonomy can raise for temporal powers, as well as the symbolic costs of attacking it.

Cinema does not differ from literature only in terms of its legitimacy, but also because of a series of factors that often intensify each other. Its audience is much larger and thus more heterogeneous and less socially selected. It risks seeming less "grown-up" to social authorities, who therefore call for or implement stronger censorship. For example, at the beginning of the twentieth century, at the very moment when censorship was lifted on the theatre, a system of pre-authorization was established for cinema, which had diverted a segment of the popular audience from the theatre to itself. Another difference is that the costs of production and distribution tend to be much higher for cinema than for literature. Cultural producers must not only ensure their own subsistence, as in other domains, but must also find the capital required to produce and distribute 
réunir les capitaux nécessaires à la production et à la diffusion des œuvres. L'instauration d'un « monde économique à l'envers » (Bourdieu 1992b) s'en trouve nécessairement compliquée. Les artistes qui veulent avoir des pratiques relativement autonomes dans la durée doivent se soucier un tant soit peu des demandes profanes et de l'étendue du public que leurs œuvres sont susceptibles de toucher. Le refus de tout calcul économique risque de les conduire à l'échec. lls·elles gagnent à exploiter les marges de liberté que laissent les " verdicts économiques ", plutôt qu'à les ignorer. Une stratégie fréquente consiste à alterner des œuvres inégalement risquées sur le plan économique ou à produire des œuvres qui, un peu comme la poésie dans les sociétés traditionnelles, s'adressent à différents publics à la fois, le public des pairs n'étant que l'un d'entre eux.

Ces arguments peuvent être étendus au journalisme. Le journalisme a lui aussi un public presque coextensif à l'espace social et son " audience de masse " a régulièrement justifié des formes de surveillance gouvernementale. Son autonomisation se heurte à une légitimité culturelle encore plus faible que dans le cas du cinéma : les produits journalistiques restent, sinon en raison de leur nature, du moins du fait du regard dont ils font l'objet, des biens encore plus périssables que les films. Le/la journaliste ou l'entreprise journalistique qui ne rencontre aucun écho immédiat ne peut pas compter, comme «l'artiste maudit » en avance sur son temps, sur une éventuelle redécouverte de son œuvre par la postérité.

La contrainte économique est peut-être moins uniforme dans le champ journalistique que dans le champ cinématographique (entre autres facteurs, la diversité des types de presse - écrite, parlée, audiovisuelle, en ligne - conduit à la coexistence d'entreprises très différentes par leurs modes de financement et le volume de capital qu'elles mobilisent). Mais elle reste plus forte qu'en matière littéraire et, comme le cinéma, le journalisme est dominé par de their works. This necessarily complicates the establishment of an "economic world turned upside down" (Bourdieu 1996). Artists who wish to maintain relatively autonomous practices must take material demands into account and must pay attention to how big their audience is likely to be. If they ignore all economic calculations, they risk failing. They benefit from exploiting the margins of freedom that "economic considerations" allow for, rather than ignoring them. A common strategy is to alternate between works with varying levels of economic risk or to make films that, a bit like poetry in traditional societies, is addressed to various audiences at once-the audience of one's peers being but one among them.

These arguments can be extended to journalism: journalism also has an audience that is nearly co-extensive with the social space, and its "mass audience" has often been the justification for various forms of government surveillance. Its autonomization is blocked by the fact that it has even less cultural legitimacy than cinema does: either by their nature or because of how they are viewed, journalistic products are even more ephemeral than films. A journalist or journalistic enterprise that is not immediately successful cannot really hope to be rediscovered later on by posterity, in the same way that an "accursed artist" who is ahead of his or her time might.

Economic pressure is perhaps less uniform in the journalistic field than in the cinematic field (among other factors, the fact that there are different forms of media-spoken, written, audiovisual, online-leads to the coexistence of enterprises that are quite different from one another in terms of how they are financed and how much capital they mobilize.) But this pressure is stronger than it is in literature, and, like cinema, journalism is dominated 
grandes entreprises où le travail est une activité fortement collective et implique une subordination à l'employeur.euse qui ne s'observe que rarement, à ce degré, en matière littéraire. Au cinéma, le système des "studios ", tel qu'il a existé aux États-Unis, a pu reléguer explicitement les réalisateurs·rices au rôle d'exécutant·e, n'ayant de marge de liberté que dans des limites déterminées par des supérieur·e·s hiérarchiques (Duval 2016 : 143-145). Les journalistes sont pour leur part très souvent dans une situation qui, à peu de choses près (comme la « clause de conscience »), est celle d'un·e salarié $\cdot e$ (ou d'un·e indépendant·e précaire) composant avec les exigences de son employeur.se. Ce phénomène a pour contrepartie une professionnalisation qui est bien supérieure à celle qu'on observe chez les écrivain·e.s mais qui n'implique pas nécessairement le désintéressement économique. En matière de journalisme, la « professionnalisation », entendue au sens que les sociologues fonctionnalistes donnaient au terme (notamment Parsons 1955), reste très partielle (Ruellan 1993). Dans le cas des rubriques économiques, elle culmine dans des régions de l'espace exposées aux ingérences de puissances économiques et reconduit fortement les injonctions de ces dernières (Duval 2004 : 110147). Autre signe de son ambiguïté : les écoles de journalisme ne sont pas les lieux d'une socialisation professionnelle entièrement contrôlée par les pairs. Leurs enseignements résultent de rapports de forces impliquant, de manière importante, des forces externes : l'État, mais aussi les entreprises de presse qui attendent surtout d'elles qu'elles forment et sélectionnent de futurs journalistes ajustés à leurs exigences (Chupin 2009).

Il est tentant de conclure que le journalisme et le cinéma ne sont pas aussi autonomes que la littérature. Si le degré d'autonomie d'un champ est une grandeur difficile à quantifier, Bourdieu ouvrait des pistes en écrivant que l'autonomie d'un champ croît avec le « degré auquel le principe de hiérarchisation externe y est subordonné by big companies, where work is highly collective and implies a degree of subordination to one's employer that is only rarely found in literature. The "studio system," as it existed in the United States, explicitly relegated directors to the role of underlings, free to act only within the limits set by their hierarchical superiors (Duval 2016: 143-145). As for journalists, apart from a few differences such as "conscience clauses," they are very often in situations quite similar to that of employees (or independent contractors with no job security), and must compromise with their employers' requirements. One consequence of this phenomenon is a level of professionalization much higher than what we observe among writers, but which does not necessarily imply economic disinterest. In journalism, "professionalization," understood in the sense that functionalist sociologists gave the term (in particular, Parsons 1955) is still far from complete (Ruellan 1993). In the case of business news, professionalization culminates in regions of the space that are exposed to interference from economic powers and it powerfully extends the latter's injunctions (Duval 2004: 110-147). Another sign of the ambiguity of journalistic professionalization is that journalism schools are not sites of professional socialization entirely controlled by peers. What they teach is a result of power dynamics that involve outside forces in a significant way-these forces include the state as well as media companies, which expect journalism schools to train and select future journalists who will fit the companies' requirements (Chupin 2009).

It is tempting to conclude that journalism and cinema are not as autonomous as literature. Although it is difficult to quantify the degree of a field's autonomy, Bourdieu hinted at how that might be done, writing that the autonomy of a field increases "to the extent that the principle of external hierarchisation there is 
au principe de hiérarchisation interne », avec la coupure entre le sous-champ de grande production et le sous-champ de production restreinte, avec "l'effet de retraduction ou de réfraction que sa logique spécifique impose aux influences [...] externes » ou encore avec l'intensité de ses transferts avec les fractions dominantes de la classe dominante (Bourdieu 1992b : 302-306). Dans ces conditions, le très fort continuum qui, dans le champ cinématographique, rend parfois indiscernables l'un de l'autre les secteurs de production large et restreinte (Duval 2016) serait un indicateur d'une faible autonomie. II en irait de même pour les échanges matrimoniaux souvent commentés entre les milieux politiques et journalistiques parisiens ou les logiques commandant l'invitation de responsables politiques à la télévision (Darras 1995). On peut rappeler aussi les effets quasi immédiats que des changements de régime politique peuvent introduire dans l'histoire de certains médias ou cinémas nationaux. Le rôle des instances de consécration spécifiques n'est, quant à lui, que partiellement comparable à ce qu'il est dans des univers plus autonomes. L'existence de festivals, de prix ou d'une critique spécialisée contribue à l'autonomie de l'univers cinématographique mais ces institutions sont, par exemple, régulièrement conduites à consacrer des œuvres relativement « commerciales » pour ne pas se voir marginalisées. La boutade souvent citée selon laquelle "Tout le monde a deux métiers : le sien et critique de cinéma " suggère, quant à elle, que la critique n'y a pas tout à fait gagné l'autorité dont elle dispose dans des domaines plus consacrés. Les instances de consécration spécifiques semblent encore plus faibles dans le cas du journalisme : aucun prix n'exerce en France des effets vraiment décisifs et « la critique des médias " est loin de ressembler à un corps de spécialistes. Le capital spécifique y est très peu institutionnalisé, ce qui le rend très difficile à objectiver

(Duval 2004 : 330-336). subordinated to the principle of internal hierarchisation," as well as with the distinction between a large-scale production subfield and a restricted production subfield, with "the effect of translation or of refraction which its specific logic imposes on external influences," and with the intensity of its transfers with the dominant fractions of the dominant class (Bourdieu 1996: 218-220). Thus, the very strong continuum within the field of cinema that sometimes renders the sectors of large-scale and restricted production indistinguishable from one another (Duval 2016) would be a sign of the field's weak autonomy. The same holds true for the often-observed intermarriages between the Parisian political and journalistic milieus, or the logics determining the invitation of political leaders onto television (Darras 1995). Here, we may also think of the nearimmediate effects that changes of political regime may have on the history of certain national media or cinema. The role played by specific consecrating institutions is only partly comparable to what we find in more autonomous universes. The existence of film festivals, prizes, and a specialized form of criticism contributes to the autonomy of the cinematic universe, but these institutions are often led to recognize relatively "commercial" works in order not to be themselves marginalized. The often-quoted joke that "Everyone has two jobs: their own and film critic" suggests that criticism has not gained the authority that it enjoys in other, more established domains. Specific consecrating institutions seem even weaker in the case of journalism: there is no journalism prize in France that has decisive effects, and "media critics" far from constitute a specialized group. Specific capital is scarcely institutionalized within journalism, which makes it very difficult to objectivise (Duval 2004: 330-336). 
II n'est pas possible cependant de s'en tenir à une vision en termes de degré d'autonomie. Le cas du journalisme le montre bien car l'autonomie de cet univers à l'évidence profondément lié au champ politique ne peut pas être intégralement pensée sur le modèle des activités artistiques. Bourdieu observe que les artistes ne peuvent obtenir de légiférer seuls en matière de forme que sur la base d'un " contrat tacite [avec] les fractions dominantes de la bourgeoisie " impliquant " qu'il[s] se tienne[nt] à l'écart des choses sérieuses, à savoir les questions sociales et politiques » (Bourdieu 1971: 87). Or, un tel « contrat tacite » est exclu dans le cas des journalistes, puisque « les questions sociales et politiques » constituent l'une de

leurs matières privilégiées.

On a l'habitude de considérer que les premiers journaux et gazettes en France datent du temps de l'absolutisme. Le pouvoir royal tend à considérer, selon une formule prêtée à Richelieu, que " seuls les ministres savent distinguer les choses qui doivent être tues et celles qu'il faut donner au public »(Wolgensinger 1989 : 31). Un pouvoir politique ne peut nier de manière plus explicite la prétention de rédacteur.rice.s de journaux à légiférer dans leur domaine. La constitution, au XVIII et au xIx siècle, d'un « espace public » (Habermas 1993 [1962]) ou, si l'on préfère, d'un champ politique concurrentiel, a marqué un changement important mais l'instauration (durable) de la « liberté de la presse » en 1881 est d'abord l'œuvre de responsables politiques animant une presse d'opinion (dont se démarquent aujourd'hui nombre d'institutions journalistiques qui, à l'image du Monde ou du Canard enchaîné, mettent une sorte de point d'honneur, pour afficher leur indépendance, à traiter pareillement les différentes forces en concurrence dans le champ politique) et des patron'ne.s de la presse à grand tirage ou des milieux d'affaires. L'autonomisation du journalisme suppose des « journalistes » s'affirmant en tant que tels et prétendant obéir à une loi propre qui, distincte de la raison d'État, comme de la discipline des partis et des «pressions » exercées par
However, it is not possible to limit oneself to a view in terms of degree of autonomy. The case of journalism proves this, since the autonomy of this universe, which clearly is closely linked to the political field, cannot be fully understood on the model of artistic activity. Bourdieu observes that artists are only able to make decisions in terms of form because there exists a "a covenant with the dominant sections of the bourgeoisie," which implies that "the artist is expected to avoid serious matters, namely social and political questions" (Bourdieu 1993). But such a "covenant" is not possible for journalists, since "social and political questions" are some of their most important subjects.

It is generally accepted that the first newspapers and gazettes in France date from the era of absolutism. Royal power considered that, as Richelieu is said to have observed, "only ministers are able to distinguish between what must be kept quiet and what must be shared with the public" (Wolgensinger 1989: 31). There can be no more explicit denial by a political power of newspaper editors' claim to set the rules for their own domain. The constitution of a "public space" (Habermas 1989 [1962]) during the 18th and 19th centuries - or, to put it another way, of a competitive political fieldmarked an important change, but the (permanent) establishment of freedom of the press in 1881 was first and foremost the work of political leaders who were active within the partisan or opinion press (today, a number of journalistic institutions distinguish themselves from this type of press. For example, Le Monde and Le Canard enchaîné make a point of honour of showing their independence by treating all the various competing forces in the political field in the same way) and the heads of large-scale press enterprises or business leaders. The autonomization of journalism presupposes the existence of "journalists" who recognize themselves as such and claim to obey a particular law, distinct from the raison d'État, as 
des pouvoirs de toutes sortes (économiques, religieux...), ferait surgir une "vérité » dictée par la seule « conscience professionnelle » et validée par les pairs, par exemple par le phénomène des reprises qui consiste, pour un média, à reproduire une information donnée par un concurrent. Ces aspirations à l'autonomie peuvent se matérialiser concrètement : il arrive que des journalistes détiennent la propriété de leur entreprise ou, comme ce fut le cas au Monde, élisent eux-

mêmes leurs dirigeant $\cdot e \cdot s$.

Ces aspirations sont-elles cependant aussi « pures 》 et " désintéressées » que dans des champs artistiques ? Même s'il place la discussion sur un terrain normatif, Michael Schudson n'a pas tort de relever qu'elles ne sont pas vraiment comparables à un « art pour l'art » (Schudson 2004). La valeur de la « vérité » qu'Albert Londres est censé avoir dévoilée tient ainsi aux effets politiques de la publication (le reportage aurait contribué à la fermeture du bagne de Cayenne). De façon générale, l'autonomie ne présente pas dans le journalisme la même dimension anti-utilitaire que dans les univers artistiques. Au contraire, le critère de « l'utilité sociale » peut être explicitement invoqué dans l'attribution des prix professionnels (Gatien 2012). Intervenant, contrairement aux artistes, directement dans les affaires politiques, les journalistes justifient souvent leur prétention à l'autonomie par le service qu'ils elles rendent à " la démocratie » ou au « public ».

Ils·elles ne sauraient opérer par ailleurs une rupture radicale avec des pouvoirs temporels qui sont aussi des sources ; il s'agit plutôt, selon la formule d'un journaliste du Canard enchaîné, d'en être « assez proche pour être informé et assez éloigné pour ne pas [leur] être lié » (Ridet $2016: 58$ ). II faut également relever que les pratiques journalistiques en apparence les plus autonomes n'échappent jamais à des formes de suspicion. On peut renvoyer sur ce point à l'analyse que Dominique Marchetti fait du « journalisme d'investigation » qui well as from party discipline and the "pressures" exerted by all sorts of powers (economic, religious, etc.); this law brings out a "truth" that is dictated solely by "professional conscience" and validated by other journalists (for example, the practice of reproducing information gathered by a competitor). These aspirations to autonomy may materialize concretely: journalists might own shares in their company or, as was once the case at Le Monde, they might elect their own leaders.

But are these aspirations as "pure" and "disinterested" as they are in the artistic fields? Although he frames the discussion in normative terms, Michael Schudson is not wrong to point out that these aspirations are not really comparable to "art for art's sake" (Schudson 2004). Thus, for example, the value of the "truth" that Albert Londres is supposed to have revealed stems from the political effects of publication (reporting is said to have contributed to the closing of the penal colony in Cayenne). In general, autonomy within journalism does not present the same anti-utilitarian aspect as it does in the artistic universes. On the contrary, the criterion of "social utility" is sometimes explicitly invoked in the attribution of professional prizes (Gatien 2012). Journalists, who unlike artists intervene directly in political affairs, often justify their claim to autonomy on the basis of the services they render to "democracy" or to "the public."

Moreover, it would not be possible for journalists to make a total break from temporal powers, which are also their sources instead, they try to be "close enough to them to be informed and far enough away not to be bound to them," as a journalist for Le Canard enchainé put it (Ridet 2016: 58). We should also note that what would appear to be the most autonomous journalistic practices never escape suspicion. Here we may refer to Dominique Marchetti's analysis of "investigative journalism" from the 1970s 
s'est développé depuis les années 1970 et 1980 (Marchetti2000) : bien qu'elle soit parfois présentée comme le produit d'une sorte d'amour pur et désintéressé de la vérité, la " révélation » d'informations qui, relatives à des dirigeants politiques ou économiques, n'accéderaient pas à l'existence publique si des journalistes ne les « sortaient ", sert toujours des intérêts, quand elle n'en est pas le produit (elle est moins souvent une information véritablement produite par le journalisme que le résultat de «fuites ») ; elle trouve de plus l'un de ses ressorts dans la démarche intéressée qui consiste pour un média à accroître ses ventes à court ou (par le biais de sa « réputation ") à moyen terme. Les bénéfices économiques que dégage ce symbole de l'indépendance journalistique qu'est Le Canard enchaîné comme le fait que le prix Pulitzer ait pu être parfois attribué par mégarde à des reportages « bidonnés » (Gatien 2012) sont d'autres manifestations de la même ambiguïté.

L'autonomie journalistique pourrait être décrite comme une forme d'illusion qui cache régulièrement une hétéronomie. Patrick Champagne évoque « une impossible autonomie » ou " une autonomie toujours à reconquérir parce que toujours menacée " (Champagne 2016 : 69) et suggère que, dans son histoire, la presse ne s'est jamais libérée de l'emprise d'un pouvoir que pour tomber sous la coupe d'un autre. La remarque se transpose dans une certaine mesure au cinéma : en Union soviétique ou, plus récemment, en Iran, des cinéastes n'ont développé des pratiques très autonomes par rapport aux contraintes économiques et au goût du « grand public » qu'à la faveur de conjonctures marquées par une très forte tutelle de l'État sur l'industrie cinématographique (Duval 2016 : 109-116, 262-263). Ces réflexions ramènent au poids des contraintes économiques et au constat que le journalisme et le cinéma ne se sont pas constitués en pures activités de spécialistes. Elles peuvent conduire aussi à distinguer les activités culturelles en fonction du degré auquel elles parviennent, en s'autonomisant, and 1980s (Marchetti 2009): although the "revelation" of information about political and economic leaders is sometimes presented at the result of a pure and disinterested love of the truth, in fact it always serves some interest, when it is not actually produced by one or more interests (such revelations are rarely truly produced by journalism; they are more often the result of "leaks"); furthermore, such revelations are also driven by media companies' interest in increasing their sales in the short or medium term (thanks to an enhanced "reputation"). The economic benefits that accrue to Le Canard enchaîné, a publication that is the very symbol of journalistic independence, as well as the fact that the Pulitzer Prize has occasionally been accidentally awarded to "fudged" reporting (Gatien 2012), are other manifestations of this same ambiguity.

Journalistic autonomy can be described as a form of illusion that frequently obscures heteronomy. Patrick Champagne speaks of "an impossible autonomy" or "an autonomy that must always be re-won, because it is always under threat" (Champagne 2016: 69), and suggests that over the course of its history, the press has always freed itself from the influence of one power only to fall under the sway of another. This observation can, to a certain extent, be transposed to cinema: in the Soviet Union and, more recently, in Iran, filmmakers have developed practices that are highly autonomous with respect to economic constraints and to the "general public's" taste, thanks to circumstances marked by strong state oversight of the film industry (Duval 2016:109-116 and 262-263). These considerations are reminders of the influence of economic constraints and of the fact that journalism and cinema are not constituted as pure specialist activities. They can also lead us to distinguish between cultural activities on the basis of the degree to which, in becoming autonomous, they succeed in becoming 
à devenir ou non indifférentes aux pouvoirs temporels. Le cinéma et surtout le journalisme diffèrent, sous ce rapport, de la poésie ou des mathématiques parce qu'ils sont restés des enjeux politiques ou économiques pour les fractions dominantes des classes dominantes. Leur autonomie, de ce fait, n'est pas seulement plus faible, elle est particulièrement réversible.

\section{La tendance à l'autonomisation des champs et les transformations contemporaines}

Une dernière analogie peut être relevée entre le journalisme et le cinéma. Elle concerne leur évolution historique et leurs transformations contemporaines. Si Bourdieu s'était intéressé très tôt à l'autonomie relative des champs de production culturelle, il insistait beaucoup dans les années 1990 sur le caractère réversible des processus d'autonomisation et alertait sur la régression qui affectait le champ intellectuel, le journalisme, l'édition ou encore la science (respectivement, Bourdieu 1992b, 1996, 1999, 2001b). II avait toujours présenté ses réflexions sur la formation des champs comme une sorte de reformulation de thèses classiques : la constitution de « sphères de valeurs » chez Max Weber ou le passage, chez Émile Durkheim, des sociétés archaïques où « toutes les formes d'activités, toutes les fonctions sont rassemblées, comme prisonnières les unes des autres" aux sociétés modernes où la religion, la science, l'économie, l'art sont différenciés (Durkheim 1955 : 191-192). Se défiant des processus linéaires ou irrépressibles, Bourdieu signalait parfois que la philosophie ou l'art avaient connu dans la Grèce antique un processus d'autonomisation, avant de connaître un mouvement inverse pendant une grande partie du Moyen Âge. La constitution des États modernes ouvrait, à ses yeux, une nouvelle époque avec l'autonomisation des juristes par rapport au pouvoir royal, puis à partir de la Renaissance surtout, celle de la science indifferent to temporal power-or do not. In this respect, cinema and especially journalism, differ from poetry or mathematics, because they continue to constitute political and economic stakes for the dominant fractions of the dominant classes. For this reason, their autonomy is not only weaker, it is easily reversible.

\section{The Trend Towards the Autonomization of Fields and Contemporary Transformations}

There is a final analogy that can be made between journalism and cinema, having to do with their historical development and contemporary transformations. While Bourdieu took an early interest in the relative autonomy of the fields of cultural production, in the 1990s he greatly emphasized the reversibility of processes of autonomization and sounded the alarm about regression in the intellectual, journalistic, editorial, and scientific fields (Bourdieu 1996; 1998; 2008b; 2004 respectively). He always presented his thoughts on field formation as a reformulation of classic arguments: Max Weber's theory of the constitution of "spheres of value," or Émile Durkheim's notion of the shift from archaic societies, where "all forms of activity and all functions were gathered together, and were, in a manner of speaking, each other's prisoners" (Durkheim 1983: 95). Bourdieu, sceptical of linear or inevitable processes, sometimes indicated that art and philosophy underwent autonomization in ancient Greece, before experiencing the reverse movement during much of the Middle Ages. To his mind, the creation of modern states opened a new era, with the autonomization of jurists from royal power, and then-especially beginning in the Renaissance-that of science and art, and, finally, with the development of capitalism, autonomization of the "economic cosmos," to use an expression of Weber's that Bourdieu was fond of citing (Weber 2001 [1905]: 106). 
et de l'art, et, avec le développement du capitalisme, celle du " cosmos économique » - pour utiliser une formule de Max Weber (Weber 2003 : 28) que Bourdieu aimait reprendre.

L'étude simultanée du journalisme et du cinéma conforte l'hypothèse d'une tendance de long terme à l'autonomisation des champs. Le rôle que la critique cinématographique a pris dans l'autonomisation du cinéma met également en valeur le caractère cumulatif du processus. La critique cinématographique dans la presse et les médias d'assez grande diffusion a en effet dû conquérir le droit de tenir sur les films un discours qui obéisse à des critères propres et non pas aux logiques hétéronomes consistant à s'aligner sur les attentes de son lectorat ou à servir les intérêts économiques des grosses sociétés cinématographiques. Certains de ses représentants, dans les années 1920, ont fait appel à la justice pour obtenir la reconnaissance de ce droit. L'existence d'une critique cinématographique suppose une autonomie relative du champ journalistique. De fait, la critique cinématographique la plus portée à valoriser les produits cinématographiques relativement autonomes par rapport aux attentes du grand public se développe préférentiellement dans des positions homologues du champ journalistique, c'est-à-dire elles-mêmes relativement autonomes par rapport aux attentes du grand public.

II faut par ailleurs relever le rôle de l'État. L'État a pris une part importante à l'autonomisation du champ cinématographique. Dès les années 1930, et plus encore après la guerre puis après 1960, il a soutenu des films « de qualité ", relevant de « l'art et essai » ou ayant de faibles chances de se rentabiliser sur le marché (Pinto 2012, Vézyroglou 2014). Une orientation similaire se repère dans les aides apportées à la presse à partir des années 1930 : elles vont prioritairement aux quotidiens « à faible ressources publicitaires » ou « à faibles ressources de petites annonces ». Les
Studying journalism and cinema side-by-side bolsters the hypothesis that there is a long-term trend towards the autonomization of fields. The role that film criticism has taken on in the autonomization of cinema also demonstrates the cumulative nature of the process. Indeed, film criticism in large-distribution press and media had to win the right to create discourse on films that would obey its own specific criteria rather than the heterogeneous logics of readers' expectations or the economic interests of major film companies. In the 1920s, some representatives of film criticism turned to the justice system in order to gain recognition of this right. The existence of film criticism presupposes the relative autonomy of the journalistic field. In fact, the type of film criticism most likely to valorize cinematic products that are relatively autonomous from the expectations of the general public tends to develop in homologous positions in the journalistic field-that is to say, in positions that are themselves relatively autonomous from the general public's expectations.

We must also note the role of the state, which has taken on a significant role in the autonomization of the cinematographic field. Beginning in the 1930s and increasing after the war and then again after 1960, the state supported "quality" or "art-house" films that were unlikely to be profitable on the market (Pinto 2012, Vézyroglou 2014). Similar concern can be discerned in state support for the press beginning in the 1930s: aid was primarily given to dailies with "low advertising revenue" or "low revenue from classifieds." The examples of journalism and cinema strengthen 
cas du journalisme et du cinéma confortent l'idée que « pendant une cinquantaine d'années - grosso modo de l'entre-deux-guerres au milieu des années 1970 [...] -, l'intervention publique [...] forme une contribution [...] à la constitution ou à la préservation de l'autonomie des champs " (Dubois 2014 : 24). Bien sûr, cet objectif ne s'affiche pas nécessairement comme tel : l'action publique invoque plus volontiers la "qualité des films » ou le «pluralisme de la presse » que « l'autonomie ». De plus, la politique cinématographique de l'État a toujours comporté, à côté d'un volet culturel, un volet industriel qui, par la force des choses, profite aussi, et souvent d'abord, à des films produits pour le marché élargi. De même, le contrôle gouvernemental de l'information sur les chaînes du monopole public dans les années 1960 et 1970 ne contribuait guère à l'autonomie journalistique. II reste que l'intervention publique, dans les décennies d'aprèsguerre, ne peut être assimilée à une simple force hétéronome ${ }^{3}$. Au minimum, l'un de ses effets a consisté à mettre en place un cadre favorable au développement de pratiques autonomes en matière de journalisme et de cinéma.

La dynamique générale est assez différente pour les trois ou quatre dernières décennies. Une montée des contraintes commerciales s'observe dans l'univers journalistique depuis le milieu des années 1990 (Bourdieu 1996, Champagne 2016, Marchetti 2010). Les chaînes de télévision généralistes sont très attentives depuis les années 1980 à leurs résultats d'audience. La presse écrite a connu un mouvement de concentration économique au profit de quelques

3. II est utile de rappeler que les peintres se sont autonomisé.e.s en rompan les liens avec l'État et que l'intervention publique en faveur du cinéma (ou du journalisme) produit des effets de dépendance. II reste des différences importantes, avec le contrôle de la culture par l'Etat dans des contextes autoritaires, en particulier s'agissant des critères et des instances fondant l'intervention publique. (Voir sur ce point Sapiro 2003). the idea that "for fifty-some years-essentially, from the interwar period to the middle of the 1970s, state intervention [...] amounted to a contribution [...] to the constitution or preservation of the autonomy of fields" (Dubois 2014: 24). Of course, the objective was not necessarily announced in those terms: state action was more likely to refer to "quality of films" or "pluralism of the press" than to "autonomy." In addition, the state's cinema policy always included, in addition to the cultural component, an industrial one, which alsoand sometimes primarily-benefited mass-market films. Similarly, government control of information on state-controlled networks during the 1960s and 1970s did not contribute to journalistic autonomy. Nevertheless, state intervention during the decades after the war cannot be compared with a simple heteronomous force. ${ }^{4}$ At a minimum, one of its effects consisted in implementing a framework favourable to the development of autonomous practices in journalism and cinema.

The overall dynamic has been quite different for the past three or four decades. An increase in commercial restrictions within the journalistic universe can be observed beginning in the mid1990s (Bourdieu 1996, Champagne 2016, Marchetti 2010). Since the 1980s, general interest television networks have been highly attentive to their audience results. The written press has been concentrated among several large industrial groups, which

4. It is useful to recall that painters became autonomous by breaking thei connections to the state and that state support for cinema (or journalism) creates effects of dependence. Significant differences remain between these cases and control of culture by the state in authoritarian contexts, in particula in terms of the criteria and authorities on which state intervention is based. For more on this, see Sapiro 2003. 
grands groupes industriels qui affichent parfois ouvertement leur souhait de disposer, au travers des journaux, d'un moyen d'influence (Bouquillon 2008 : 57-60). Confrontés à une érosion de leur lectorat et à une concurrence accrue sur le marché publicitaire, les grands titres de la presse nationale quotidienne ont perdu nombre d'attributs de leur indépendance économique et renoncé à certaines « exigences » qui faisaient leur réputation. Contrairement aux grandes créations de l'après-guerre (Le Monde, L'Express, Le Nouvel Observateur, Libération, etc.), les médias qui ont monté en puissance au cours des trente dernières années se caractérisent moins par des aspirations à l'autonomie que par leur capacité à toucher un large public ou à attirer les budgets publicitaires : presse magazine fondée sur des techniques de marketing, quotidiens gratuits fabriqués à très bas coûts et réduits à un journalisme de reprise, médias d'information instantanée sur Internet, chaînes d'information continue... Quelques sites d'information sur Internet pourraient conduire à nuancer cette analyse, mais il faut encore rappeler leur précarité économique et souligner qu'ils ne font souvent que remplir une fonction auparavant prise en charge par la presse écrite, sans avoir l'audience de celle-ci.

Au cinéma, une dynamique importante tient à la montée en puissance de blockbusters conçus pour concentrer, en un laps de temps réduit, une grosse part de la fréquentation cinématographique. Cette tendance apparue à Hollywood dans les années 1970 est à l'origine d'un accroissement très net de la part de marché des États-Unis sur les marchés européens. En France, la production nationale n'a réussi à contenir cette offensive qu'en développant des productions visant elles aussi à saturer le marché. Avec cette dynamique, l'accès aux salles et aux grands médias des créateur.rice-s porté.e.s à une relative autonomie est devenu plus difficile, le goût du public pour le " cinéma d'auteur·e » semblant par ailleurs diminuer. sometimes openly proclaim their wish to exercise influence through newspapers (Bouquillon 2008: 57-60). Confronted with a dwindling readership and increased competition, the major national dailies have lost many of the attributes of their economic independence and have abandoned some of the "exigencies" on which they had built their reputation. Unlike the major newspapers created after the war (Le Monde, L'Express, Le Nouvel Observateur, Libération, etc.), the media companies that have gained power over the past thirty years are characterized less by aspirations to autonomy and more by their capacity to reach a large audience or to attract advertising revenue: these include news magazines based on marketing techniques, free dailies produced very cheaply that simply reprint journalism from elsewhere, instantaneous news media on the internet, twenty-hour news stations, etc. There are some online news sites whose existence perhaps requires us to qualify this analysis somewhat, but they are often economically precarious and play a role previously played by the written press, but without the audience the latter had.

In the film industry, a significant dynamic has resulted from the increased power of blockbusters-films created to concentrate movie-going into a short period of time. This trend began in Hollywood in the 1970s and is responsible for the sharp increase of the United States' market share in European markets. In France, national film production has only been able to contain this offensive by developing films that are also intended to saturate the market. As a result of this dynamic, it has become more difficult for relatively autonomous creators to access theatres and the major media outlets; at the same time, the public's taste for independent art films seems to have diminished. 
Au cours des dernières décennies, une tendance importante, dans le journalisme et le cinéma, comme dans d'autres espaces de production culturelle, réside donc dans la montée en puissance des logiques économiques et dans un renforcement du pôle de diffusion élargie au détriment du pôle relativement autonome de diffusion restreinte. Des forces plus anciennes œuvrant à une autonomisation croissante ont certes continué à produire des effets et la nouvelle conjoncture a revigoré des îlots ou des niches d'« indépendance » (Noël 2012), mais il s'agit là de tendances de moindre intensité. Comme cela avait été le cas dans les décennies antérieures, les transformations du journalisme et du cinéma ont interagi. Les chaînes de télévision qui étaient déjà des lieux centraux de promotion et de diffusion des films sont devenues des actrices majeures de l'économie du cinéma et, sous l'effet des logiques commerciales dans lesquelles elles étaient entraînées, les plus importantes d'entre elles ont donné plus de visibilité aux films visant à «saturer le marché », les productions plus confidentielles étant de plus en plus reléguées sur des chaînes à faible audience. La critique cinématographique voit, quant à elle, la place qui lui est réservée dans les journaux se réduire. Son autonomie est parfois mise en question dans les rédactions, le contexte marqué par l'érosion des lectorats attisant la crainte de « creuser le fossé entre le public et la critique ».
Over the past few decades, there has thus been a significant trend in both journalism and cinema - as well as in other spaces of cultural production-towards increased power of economic logics and a stronger pole of large-scale distribution, to the detriment of the relatively autonomous pole of restricted distribution. Older forces pushing towards autonomization have continued to produce effects, and new circumstances have reinvigorated islets or niches of "independence" (Noël 2012: 2015), but those trends are not as strong. As in earlier decades, there has been interaction between the transformations of journalism and of cinema. Television networks, which were already central sites for the promotion and distribution of film, became major actors in the economy of cinema and, under the effects of the commercial logics they were now part of, the biggest among them gave more visibility to films intended to "saturate the market," while smaller productions became increasingly relegated to networks with smaller audiences. As for film criticism, the room reserved for this in the press has been reduced. Its autonomy is sometimes called into question, and reduced readership sparks fear of widening the gap between the public and criticism. 


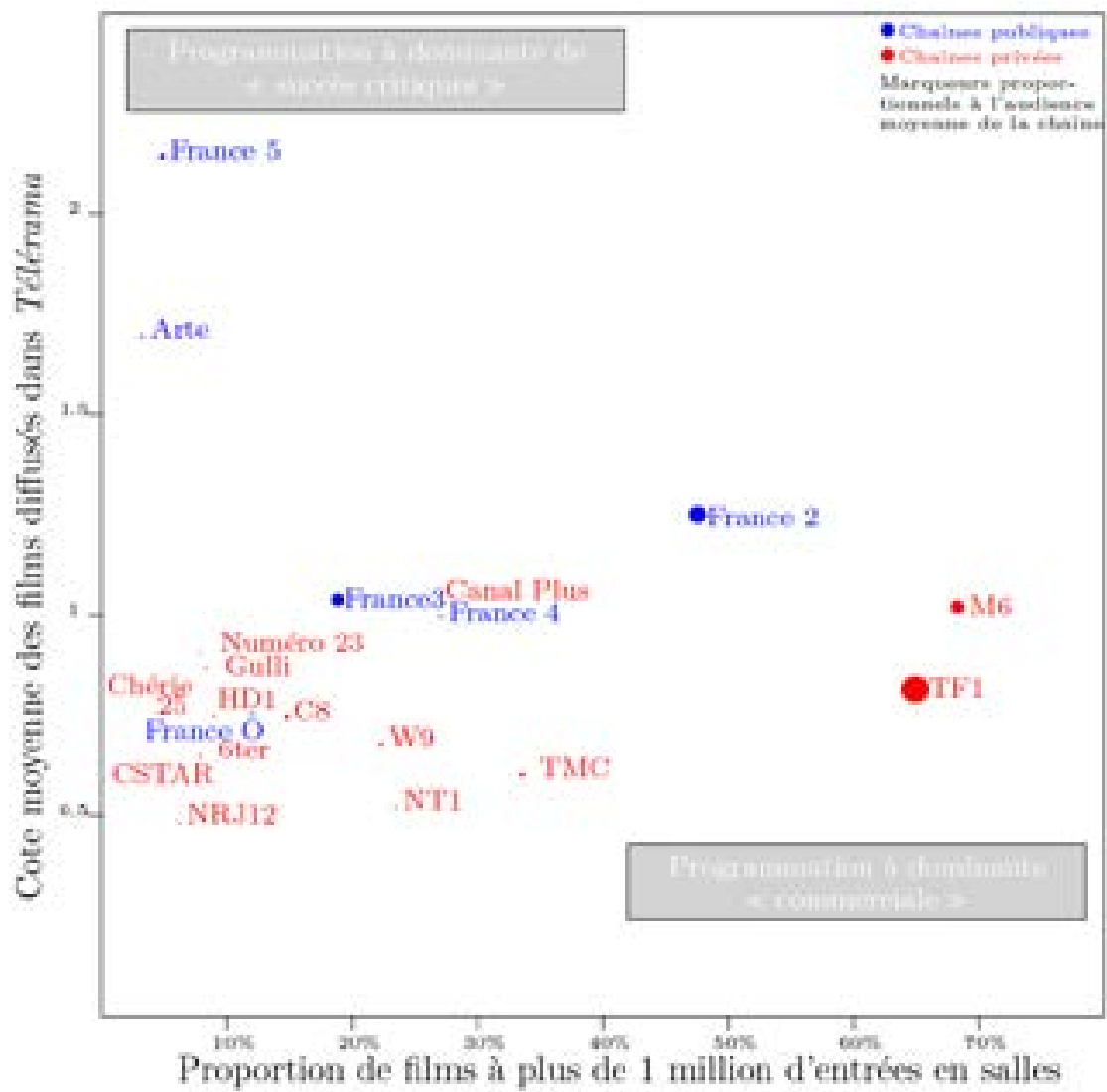

Fig. 2

La programmation des films sur les chaînes de télévision en 2017 montre qu'à la faveur de l'homologie entre les espaces culturels, les grandes chaînes aujourd'hui tendent à s'opposer selon une opposition du même type de celle qui s'établit, au sein de la production cinématographique, entre les films les plus « commerciaux " et ceux qui recueillent (exclusivement) un " succès critique ».

Source : graphique de l'auteur.

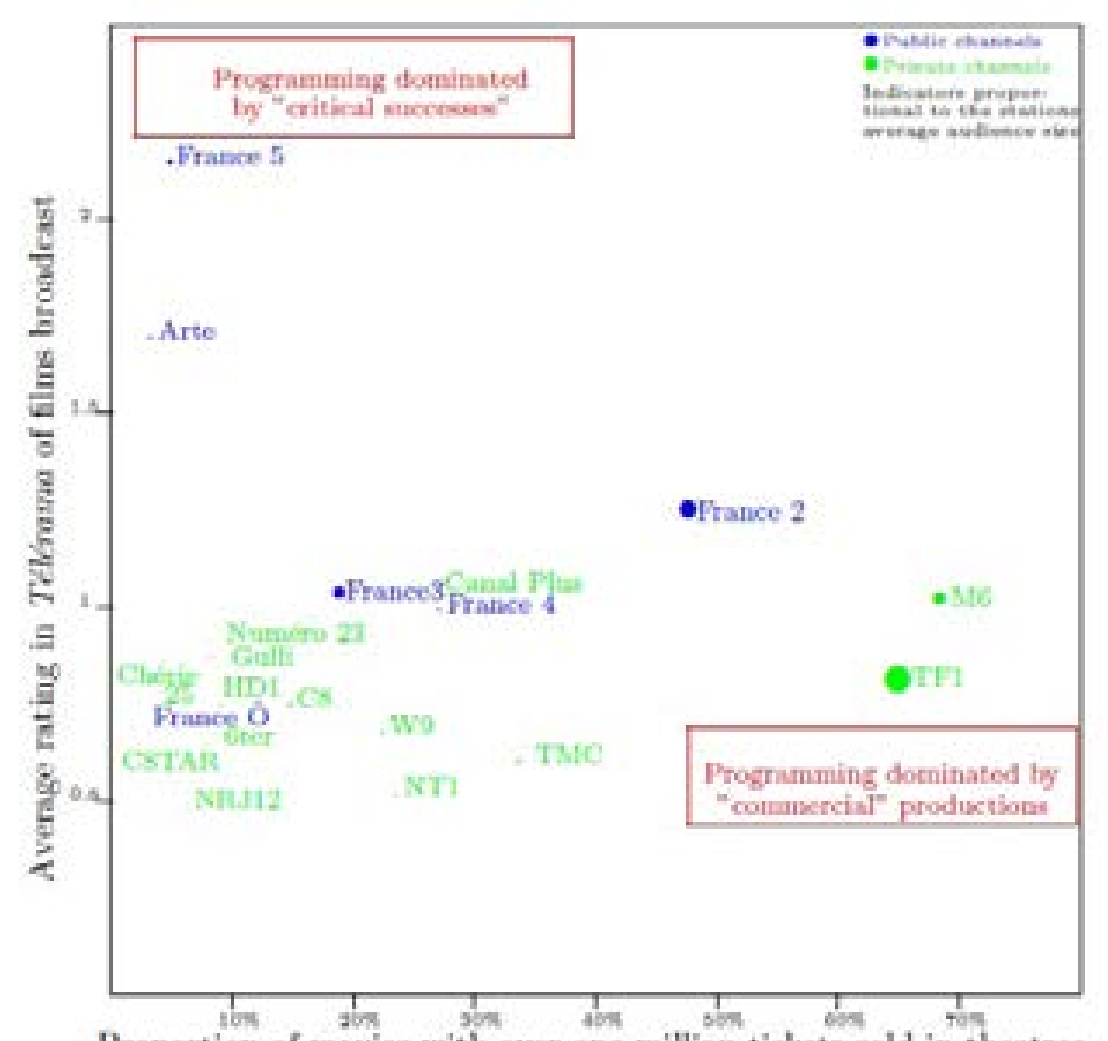

Proportion of movies with over one million tickets sold in thentres

Fig. 2

The broadcast of films on TV channels in 2017 shows that, as a result of the homology that exists between cultural spaces, the major channels tend to fall into the same opposition that exists in movie production between more "commercial" films and those that are (exclusively) "critical successes." 
Au cours des dernières décennies, une tendance importante, dans L'État a participé sur la période récente à la montée de logiques hétéronomes (Dubois 2014). Il a par exemple renoncé au monopole public en matière de télévision et il a contribué, au moins par sa passivité, aux phénomènes de concentration économique qui se sont accélérés à partir des années 1980. À partir des années 1980, l'action publique a pris des distances avec l'hostilité initiale du ministère des Affaires culturelles à l'égard des « industries culturelles » (Dubois 1999). La politique cinématographique n'a pas échappé au tournant néolibéral. L'idée selon laquelle l'État devait soutenir en priorité des productions non rentables est devenue moins consensuelle, l'accent étant plus souvent mis sur l'importance de conforter des productions " commerciales " susceptibles d'être compétitives face aux blockbusters hollywoodiens.

Les dernières décennies marquent-elles l'inversion d'une tendance de très long terme qui semblait porter à une autonomie croissante des champs de production culturelle ? II faut d'abord rappeler que cette tendance avait compté des interruptions et des retours en arrière. L'instauration de la « liberté de la presse », par exemple, ne s'était pas opérée de façon continue en France mais par une série d'avancées et de reculs au cours des XVIII et XIX siècles. De même, l'autonomisation du champ cinématographique, après une phase active dans les années 1920, avait plutôt régressé dans les années 1930 et pendant la Deuxième Guerre mondiale. Ensuite, ce qui se joue aujourd'hui est, à la faveur d'une transformation des rapports de forces à l'intérieur du champ du pouvoir, la subordination croissante d'un grand nombre d'espaces sociaux à des exigences venues du champ économique. Le mouvement n'épargne pas l'État et le champ politique : les appels émanant de ces deux univers à une sorte de mobilisation générale en faveur de la compétition économique traduisent une réduction de leur autonomie par rapport au champ économique. Le néolibéralisme renvoie à une plus forte
In recent times, the state has participated in the increase of heteronomous logics (Dubois 2014). For example, it has given up its monopoly on the television market, and has contributedat least by its inaction-to phenomena of economic concentration that accelerated beginning in the 1980s. In the 1980s, state action began to move away from the Ministry of Cultural Affairs' initial hostility towards the "cultural industries" (Dubois 1999). The state's cinema policy has not escaped the neo-liberal turn. The consensus that the state should prioritize support for productions that are not profitable has been eroded, and emphasis is more often put on the importance of bolstering "commercial" films that can compete with Hollywood blockbusters.

Do the past few decades indicate the reversal of a very longterm trend that seemed to be moving in the direction of increased autonomy for fields of cultural production? We must recall that this trend has always included interruptions and reversals. For example, establishment of "freedom of the press" was not a continuous process in France, but rather a series of forward and backward steps made over the course of the 18th and 19th centuries. Similarly, after an active phase in the 1920s, autonomization of the cinematic field regressed in the 1930s and during the Second World War. Today, as a result of a transformation of power relations within the field of power, many social spaces are becoming increasingly subordinate to requirements from the economic field. This shift has not spared the state or the political field: the calls that come from these two universes for a kind of general mobilization towards economic competition is an expression of the reduction of their own autonomy with respect to the economic field. Neoliberalism corresponds to stronger autonomization of the economic field and its heightened influence over other social spheres. Neoliberalism is in continuity with classical English liberalism-though 
autonomisation du champ économique et à son emprise renforcée sur les autres sphères sociales. S'il le renouvelle légèrement, il s'inscrit dans la continuité du libéralisme anglais que Karl Polanyi, par exemple, analysait dans le vocabulaire de l'autonomie : la constitution de l'économie en "institutions séparées 》, son " désencastrement ", consiste à sommer " la société [de] prendre une forme telle qu'elle permette à ce système [économique] de

fonctionner suivant ses propres lois » (Polanyi 1983 [1944] : 88).

On pourrait avancer l'hypothèse que certains champs perdent en autonomie par rapport à un champ économique qui gagne en autonomie. Une telle formulation a au moins deux avantages. Elle suggère d'abord qu'idéalement la notion d'autonomie ne devrait pas être utilisée sans qu'on ait présent à l'esprit l'état des relations d'interdépendance entre les champs à un moment donné. Elle suggère ensuite que la rupture des dernières décennies ne concerne pas véritablement le processus de formation des champs. II n'y a pas de retour à « l'état primitif d'indivision »(Durkheim 1955 : 191). Le « cosmos économique » poursuit un mouvement d'expansion qui a peut-être simplement été ralenti, ou partiellement suspendu, pendant les décennies d'après-guerre, à la faveur de la " grande transformation » qu'annonçait Polanyi au lendemain de la Deuxième Guerre mondiale. Quant aux univers qui perdent en autonomie, ils continuent de fonctionner, sous beaucoup d'aspects, comme des champs. Simplement, la concurrence oppose peut-être de plus en plus des entreprises et des agent.e.s qui, sous l'apparence de poursuivre des enjeux spécifiques, se livrent aujourd'hui souvent une concurrence de nature largement économique.

\section{Conclusion}

L'analyse comparative esquissée dans ce texte rappelle que les aspirations des praticiens à l'autonomie sont loin d'être absentes ou secondaires dans des univers comme le journalisme ou le cinéma it alters it slightly-which Karl Polanyi, for example, analysed in terms of autonomy: the constitution of the economy in "separate institutions," and its "de-integration" are indicative of the imperative that "society must be shaped in such a manner as to allow that system to function according to its own laws" (Polanyi 1944: 60).

We may advance the hypothesis that some fields lose autonomy with respect to an economic field that gains in autonomy. There are at least two advantages to formulating things in this way. First, it suggests that, ideally, the notion of autonomy should not be used unless we have in mind the state of the relations of interdependence between fields at a given moment. Second, it suggests that the shift during recent decades does not really concern the process of field formation. There has been no return to "the primitive undivided state" (Durkheim 1983: 94). The "economic cosmos" continues a movement of expansion that was perhaps simply slowed, or partially suspended, during the decades after the Second World War, as a result of the "great transformation" Polanyi heralded. As for those universes that lose autonomy, they continue to operate like fields in many respects. It is simply that competition increasingly sets businesses and agents against one another who, while appearing to pursue specific goals, are often competing against one another in a competition that is largely economic in nature.

\section{Conclusion}

The comparative analysis outlined in this text reminds us that the aspirations to autonomy are far from absent or secondary in universes such as journalism or cinema, which are exposed to a sort of fundamental heteronomy. It is just that autonomy is more 
exposés à une sorte d'hétéronomie fondamentale. L'autonomie y est simplement plus problématique et plus précaire que dans les univers qui, comme les mathématiques ou la poésie d'avantgarde, ont pu se constituer en activités de spécialistes. L'analyse comparative, en même temps, dissuade de conclure à une simple différence de degré. L'autonomie prend aussi des formes spécifiques dans ces univers que l'on peut qualifier de « cadets » par rapport aux espaces sociaux pionniers qui leur fournissent des ressources pour s'autonomiser mais sont aussi tentés d'exercer une tutelle sur eux. L'étude de ces univers invite aussi à redonner toute son importance au fait que l'autonomie reste toujours relative et que, dans un monde social constitué de relations d'interdépendance, elle ne peut advenir que dans et par la dépendance ; elle survient en tout cas régulièrement par des voies inattendues, "complexes, sinon impénétrables » (Bourdieu 1992b : 81).

Les réflexions présentées dans ce texte ont une autre conséquence. Un champ fortement autonome est, pour le chercheur, un objet autonomisable en ce sens qu'il " n'est pas pris dans un réseau de relations dont il tient l'essentiel de ses propriétés » (Bourdieu 1992a : 200). L'étude des univers les plus autonomes peut en ce sens inciter à les étudier isolément. De fait, c'est la forte autonomie du champ littéraire ou du champ scientifique qui garantit la pertinence d'une sociologie de la littérature ou d'une sociologie de la science. Travailler sur des espaces plus hétéronomes, comme le journalisme et le cinéma, attire, au contraire, l'attention sur les relations entre les champs. Les transformations contemporaines du journalisme et du cinéma font réapparaître l'intérêt d'une sociologie générale qui pourrait invoquer une image que proposait Bourdieu (1994) : assemblage de champs plus ou moins connectés les uns aux autres, le monde social pourrait être conçu sur le modèle d'un mobile à l'équilibre toujours précaire et changeant, un mouvement imprimé en l'un de ses points étant susceptible de se propager aux autres éléments. Julien Duval

EHESS - Centre européen de sociologie et de science politique-Centre de sociologie européenne problematic and precarious there than it is in universes such as mathematics or avant-garde poetry, which have been able to constitute themselves as specialist activities. At the same time, comparative analysis dissuades us from concluding that there is a mere difference of degree. Autonomy also takes on specific forms in these universes that can be described as "junior" with respect to the pioneering social spaces that provide them with resources for autonomy but which are also tempted to exert tutelage over them. Studying these universes invites us to give full weight to the fact that autonomy is always relative and that, in a social world that comprises relations of interdependence, it can only be achieved in and by dependence; it frequently arrives by unexpected routes that are "complex, if not impenetrable" (Bourdieu 1996: 52).

There is another consequence of the reflections presented in this article. For researchers, highly autonomous fields are autonomizable objects in the sense that they are not "enmeshed in a network of relations that assign [their] most distinctive properties" (Bourdieu 1992: 228). In this way, focusing on the most autonomous universes can lead to studying them in isolation. In fact, it is the strong autonomy of the literary and scientific fields that ensures the relevance of the sociology of literature or the sociology of science. Working on more heteronomous spaces such as journalism or cinema draws attention, conversely, to the relations between fields. The contemporary transformations of journalism and cinema demonstrate the importance of a general sociology that would recall the image proposed by Bourdieu (1994): as an assemblage of fields more or less connected to one another, the social world can be envisioned on the model of a mobile whose balance is always precarious and changing, where any movement at any one point is likely to spread to other elements.

Julien Duval

EHESS - Centre européen de sociologie

et de science politique-Centre de sociologie européenne 


\section{Références bibliographiques}

AlPERS Svetlana (1991) [1988]. L'Atelier de Rembrandt. La liberté, la peinture et l'argent trad. de l'anglais Jean-François Sené. Paris, Gallimard.

Bellanger Claude (1972). Histoire générale de la presse française. Paris, Presses Universitaires de France.

Bouquiluion Philippe (2008). Les Industries de la culture et de la communication. Les stratégies du capitalisme. Grenoble, Presses Universitaires de Grenoble.

BOURDiEu Pierre (1971). « Le marché des biens symboliques ». L'Année sociologique, 22 : 49-126.

Bourdieu Pierre (1979). La Distinction. Critique sociale du jugement. Paris, Minuit.

Bourdieu Pierre (1992a). Réponses. Pour une anthropologie réflexive. Paris, Seuil.

Bourdieu Pierre (1992b). Les Règles de l'art. Genèse et structure du champ littéraire. Paris, Seuil.

Bourdieu Pierre (1994). «Questions à Pierre Bourdieu ». In MAUGeR Gérard \& PINTO Louis (dir.). Lire les sciences sociales, 1989-1992, vol. I. Paris, Belin : 311-332

Bourdieu Pierre (1996). Sur la télévision. Paris, Raisons d'agir.

BOURDIEU Pierre (1999). «Une révolution conservatrice dans l'édition 》. Actes de la recherche en sciences sociales, 126-127 : 3-28.

Bourdieu Pierre (2000). Propos sur le champ politique. Lyon, Presses Universitaires de Lyon.

\section{References}

AlPERS Svetlana (1988). Rembrandt's Enterprise. The Studio and the Market. Chicago, The University of Chicago.

Bellanger Claude (1972). Histoire générale de la presse française. Paris, Presses Universitaires de France.

Bouquillion Philippe (2008). Les Industries de la culture et de la communication. Les stratégies du capitalisme. Grenoble, Presses Universitaires de Grenoble.

Bourdieu Pierre (1984). Distinction. A Social Critique of the Judgement of Taste. English translation by Richard Nice. London, Routledge \& Kegan Paul.

BOURDIEU Pierre (1985). "The Market of Symbolic Goods." English translation by Rupert Swyer. Poetics, 14(1-2): 13-44.

Bourdieu Pierre (1992). An Invitation to Reflexive Sociology. Cambridge, Polity Press.

Bourdieu Pierre (1994). "Questions à Pierre Bourdieu." In MAuger Gérard \& PINTO Louis (eds.). Lire les sciences sociales, 1989-1992, Volume 1. Paris, Belin: 311-332.

Bourdieu Pierre (1996). The Rules of Art. English translation by Susan Emanuel. Cambridge, Polity.

BOURDIEU Pierre (1998). On Television and Journalism. English translation by Priscilla Parkhurst Ferguson. London, Pluto Press.

Bourdieu Pierre (2000). Propos sur le champ politique. Lyon, Presses Universitaires de Lyon.

BouRdieu Pierre (2001). "Bref impromptu sur Beethoven, artiste entrepreneur." Sociétés et représentations, 11: 13-18. 
BOURDIEU Pierre (2001a). « Bref impromptu sur Beethoven, artiste entrepreneur ». Sociétés et représentations, $11: 13-18$.

Bourdieu Pierre (2001b). Science et de la science et réflexivité. Paris, Raisons d'agir.

Bourdieu Pierre (2001c). Contre-feux 2. Paris, Raisons d'agir.

Bourdieu Pierre (2002). Interventions, 1961-2001. Marseille, Agone.

BouRdieu Pierre (2013). Manet. Une révolution symbolique. Paris, Raisons d'agir/Seuil.

Champagne Patrick (2016). La Double dépendance. Sur le journalisme. Paris, Raisons d'agir.

ChupIN Ivan (2009). "Sciences sociales et formations en journalisme : émergence d'un nouvel enjeu de distinction ". Questions de communication, $16: 45-70$

DARRAS Éric (1995). " Le pouvoir "médiacratique" ? Les logiques du recrutement des invités politiques à la télévision ». Politix, 30 : 183-198.

Dreyer Carl Th. (1968). « Lettre ». Cahiers du cinéma, $207:$ 12-13.

DuBoIs Vincent (1999). La Politique culturelle. Genèse d'une catégorie d'intervention publique. Paris, Belin.

DuBoIs Vincent (2014). « L'action de l'État, produit et enjeu des rapports entre espaces sociaux ». Actes de la recherche en sciences sociales, 201-202 : 11-25.

Durkheim Émile (1955). Pragmatisme et sociologie. Paris, Vrin.

DuvaL Julien (2004). Critique de la raisonjournalistique. Les transformations de la presse économique en France. Paris, Seuil.
Bourdieu Pierre (2003). Firing Back. Against the Tyranny of the Market 2. English translation by Loïc Wacquant. London, Verso.

Bourdieu Pierre (2004). Science of Science and Reflexivity. English translation by Richard Nice. Cambridge, Polity.

Bourdieu Pierre (2008a). Political Interventions. Social Science and Political Action. English translation by David Fernbach. London, Verso.

BOURDIEU Pierre (2008b). "A conservative revolution in publishing." English translation by Ryan Fraser. Translation Studies, 1(2): 123-153.

Bourdieu Pierre (2017). Manet. A Symbolic Revolution. English translation by Peter Collier and Margaret Rigaud-Drayton. London, Polity.

Champagne Patrick (2016). La Double Dépendance. Sur le journalisme. Paris, Raisons d'agir.

CHuPIN Ivan (2009). "Sciences sociales et formations en journalisme: émergence d'un nouvel enjeu de distinction." Questions de communication, 16: $45-70$.

DARRAS Éric (1995). "Le pouvoir 'médiacratique'? Les logiques du recrutement des invités politiques à la télévision." Politix, 30: 183-198.

Dreyer Carl Th. (1968). "Lettre.” Cahiers du cinéma, 207: 12-13.

Dubols Vincent (1999). La Politique culturelle. Genèse d'une catégorie d'intervention publique. Paris, Belin.

DuBols Vincent (2014). "L'action de l'État, produit et enjeu des rapports entre espaces sociaux." Actes de la recherche en sciences sociales, 201202: 11-25.

DurkHeim Émile (1983). Pragmatism and sociology. English translation by J.C. Whitehouse. Cambridge, Cambridge University Press 
Duval Julien (2016). Le Cinéma au $x x^{e}$ siècle. Entre loi du marché et règles de l'art. Paris, CNRS Éditions.

FERENCZI Thomas (1993). L'Invention du journalisme en France. Naissance de la presse moderne à la fin $d u x i x^{e}$ siècle. Paris, Plon.

Gatien Emmanuelle (2012). Prétendre à l'excellence. Prix Albert Londres, prix journalistiques et transformations du journalisme. Paris, Fondation Varenne/L.G.D.F.

Goulet Vincent (2009). « Dick May et la première école de journalisme en France. Entre réforme sociale et professionnalisation ». Questions de communication, $16: 27-44$

Habermas Jürgen (1993) [1962]. L'Espace public, trad. de l'allemand Marc B. de Launay. Paris, Payot.

KANT Emmanuel (1997) [1798]. Le Conflit des facultés en trois sections, trad. de l'allemand Jean Gibelin. Paris, Vrin.

MARCHETTI Dominique (2000). « Les révélations du journalisme d'investigation ». Actes de la recherche en science sociales, 131-132 30-40.

MARCHETtI Dominique (2010). Quand la santé devient médiatique. Les logiques de production de l'information dans la presse. Grenoble, Presses Universitaires de Grenoble.

MARY Philippe (2006). La Nouvelle Vague et le cinéma d'auteur. Socioanalyse d'une révolution artistique. Paris, Seuil.

NoËL Sophie (2012). L'Édition indépendante critique. Engagements politiques et intellectuels. Lyon, Presses de l'ENSSIB.

Parsons Talcott (1955) [1937]. Éléments pour une sociologie de l'action. Traduit de l'anglais par François Bourricaud. Paris, Plon.
DUval Julien (2004). Critique de la raison journalistique. Les transformations de la presse économique en France. Paris, Seuil.

Duval Julien (2016). Le Cinéma au xxe siècle. Entre loi du marché et règles de l'art. Paris, CNRS Éditions.

FERENCZI Thomas (1993). L'Invention du journalisme en France. Naissance de la presse moderne à la fin $d u x I x^{e}$ siècle. Paris, Plon.

Gatien Emmanuelle (2012). Prétendre à l'excellence. Prix Albert Londres, prix journalistiques et transformations du journalisme. Paris, Fondation Varenne/L.G.D.F.

Goulet Vincent (2009). "Dick May et la première école de journalisme en France. Entre réforme sociale et professionnalisation." Questions de communication, 16: $27-44$

Habermas Jürgen (1989) [1962]. The Structural Transformation of the Public Sphere. An Inquiry into a Category of Bourgeois Society. English translation by Thomas Burger and Frederick Lawrence. Cambridge, Polity.

Kant Immanuel (1992) [1798]. The Conflict of the Faculties. English translation by Mary J. Gregor. Reno, University of Nebraska Press.

MARCHETTI Dominique (2009). "The Revelations of Investigative Journalism in France." English translation by Jean Morris. Global Media and Communication, 5(3): 353-388.

MARCHETTI Dominique (2010). Quand la santé devient médiatique. Les logiques de production de l'information dans la presse. Grenoble, Presses Universitaires de Grenoble.

MARY Philippe (2006). La Nouvelle Vague et le cinéma d'auteur. Socioanalyse d'une révolution artistique. Paris, Seuil.

NoËL Sophie (2012). L'Édition indépendante critique. Engagements politiques et intellectuels. Lyon, Presses de l'ENSSIB. 
PInTo Aurélie (2012). Les Salles de cinéma d'art et d'essai. Sociologie d'un label culturel entre marché politique et politique publique. Thèse de doctorat en sociologie. Amiens, Université de Picardie Jules Verne.

Polany Karl (1983) [1944]. La Grande Transformation. Aux origines politiques et économiques de notre temps, trad. de l'anglais Catherine Malamoud. Paris, Gallimard.

RuelLAN Denis (1993). Le Professionnalisme du flou. Identité et savoir-faire des journalistes français. Grenoble, Presses Universitaires de Grenoble.

SAPIR Edward (1967) [1949]. Anthropologie, t. 1 : Culture et personnalité., trad. de l'anglais Christian Baudelot \& Pierre Clinquart. Paris, Minuit.

SAPIRO Gisèle (2003). "The literary field between the state and the market », Poetics, 31(5-6) : 441-464.

Schudson Michael (2004). «Autononomy from what? ». In BEnson Rodney \& Neveu Erik (dir.). Bourdieu and the Journalistic Field. Londres, Polity : 214-223.

Vezyroglou Dimiti (dir.) (2014). Le Cinéma. Une affaire d'État (19451970). Paris, La Documentation française.

Weber Max (2003) [1905]. L'Éthique protestante et l'esprit du capitalisme, trad. de l'allemand Jean-Pierre Grossein. Paris, Gallimard.

Wolgensinger Jacques (1989). L'Histoire à la Une. La grande aventure de la presse. Paris, Gallimard.
Parsons Talcott (1937). The Structure of Social Action. New York, McGrawHill.

Pinto Aurélie (2012). Les Salles de cinéma d'art et d'essai. Sociologie d'un label culturel entre marché politique et politique publique. $\mathrm{PhD}$ dissertation, Sociology. Amiens, Université de Picardie Jules Verne.

Polany Karl (1944). The Great Transformation. New York, Farrar \& Rinehart.

RIDET Philippe (2016). "On assume notre côté vintage." $M$ - Le Magazine du Monde, 9 December: 53-58.

Ruellan Denis (1993). Le Professionnalisme du flou. Identité et savoir-faire des journalistes français. Grenoble, Presses Universitaires de Grenoble.

SAPIR Edward (1949). Selected Writings in Language, Culture and Personality. Berkeley, University of California Press.

SAPIRO Gisèle (2003). "The literary field between the state and the market." Poetics, 31(5-6): 441-464.

SCHUDSON Michael (2004). "Autononomy from what?" In BENSon Rodney \& NeVEu Erik (eds.). Bourdieu and the Journalistic Field. London, Polity: 214-223.

Vezyroglou Dimiti (ed.) (2014). Le Cinéma ? Une affaire d'État (19451970). Paris, La Documentation française.

Weber Max (2001) [1905]. The Protestant Ethic and the Spirit of Capitalism. English translation by Talcott Parsons. London, Routledge.

Wolgensinger Jacques (1989). L'Histoire à la Une. La grande aventure de la presse. Paris, Gallimard. 